\title{
Media Narratives of Kashmir Unrest in July 2016: A Comparative Analysis of Regional Newspapers
}

\author{
Archana Kumari ${ }^{1}$ and Mr. Ashish Kohli ${ }^{2}$
}

\begin{abstract}
Narrative is realised in many different media. It is all about the art of telling stories which media has been doing efficiently since its inception so much so that the piece of information printed in newspapers are called stories. Kashmir unrest is a 50 years long story of Post-Independence India and it is running in the veins of every Indian. Also, it develops a new story of conflicts which in turns becomes a narrative within the Jammu and Kashmir state. When we start telling story of Kashmir unrest, we have two narratives within the regional media itself: One is from Kashmir and other is from the Jammu. Both the narratives are also the part of conflict within. Both the regions have their own colour and text ideology to report the same incident of the same day and same time to cater their respective audiences. The media narratives for both the states are different; one to cater the non-Kashmiri audiences and other for the Kashmiri audience only. The narratives of the incidents presented by newspapers of both the regions of Jammu and Kashmir valley is highly influenced by the contrast ideologies of the people in these two regions. Since the newspapers are catering to the people of these two regions, so the tone and texture of news is kept according to them. This paper tries to compare the narratives of prominent newspapers of Jammu region and Kashmir region during the Kashmir unrest in July 2016 during Burhan Wani encounter.
\end{abstract}

Keywords: Narrative, Kashmir unrest, Conflict, Encounter.

\section{Introduction}

The world we are witnessing today; with various versions of truth created by media; is very difficult to understand in one dimension. There are many dimensions of reality created by media these days through 'narratives'. It is also described by Fulton, "a world dominated by print and electronic media, our sense of reality is increasingly structured by narrative" (2005). It seems to be difficult to understand what reality is and what is not from the prism of media. But the irony is that we must depend upon media for any small and big information. Media presents various versions of reality through texts, pictures, audio and visual packages in the form of stories. Continuous narration of such news stories creates the perception of people towards reality. As Car suggest, "once we move beyond seeing film and television programs as transparent representation of the world, we need to consider some of the ways in which media texts mediate the world to us. One of the most important of these is through the codes and conventions of narratives." (n.d.)

Narrative is the way; the different elements in a story are organized to make a meaningful story.

1 Assistant Professor, Department of Mass
communication and New Media, Central
University of Jammu, Rahya-Suchani, Bagla Dist
- Samba, Jammu

${ }^{2}$ Freelance Journalist
The word derives from the Latin verb narrate, "To tell". In the non-fictional narratives; media and journalism have also made their place and media narratives came into existence. Now, media narratives or narratives in the media are terms for storytelling. Some of these elements can be fact as in a documentary or characters and action as in a drama.

It can be said that in India, the print media has come a long way where journalism started with a mission but became profession in later days and it would not be wrong if we say today it is more like public relations and narrations with a motto to form favourable opinion. It can also be said that in India the media is not only setting agenda but working hard to make it successful. It is hard to understand whether media is shaping public opinion or audiences' choices are shaping the media. Similar situation is being witnessed in Jammu \& Kashmir too. There is a stark contrast in the ideologies of the people of Jammu region and Kashmir valley region, so the demand of treatment to the stories or narration of stories in newspapers is also in contrast to each other. There are more than 100 English newspapers in Jammu and Kashmir (http://rni.nic.in/display_state.asp, 2017) but The Daily Excelsior is highest circulated English daily of Jammu region with circulation of nearly $2.3 \quad$ lacs (http://www.dailyexcelsior.com/about-us, 2017)and The Greater Kashmir (http://www.4imn.com/reviews/14976.htm, 
2016) is highest circulated English daily of Kashmir valley. So, this research aims to analyse the narration of Kashmir unrest in July 2016 during the encounter of Burhan Wani; by these two newspapers and how they framed the same issue by using different narratives from the storytelling to the graphics and also to the color ideology.

\section{Review of Literature:}

Existing literature relevant to this research can be seen by various perspectives, which are:

i. Kashmir on the boil: a timeline by Meenakshi R- a special article published by The Hindu in 2016 when Kashmir was witnessing the unrest after the killing of the Militant Burhan Wani. This article tells us the various incidents occurred after the killing of the Burhan Wani from the date of killing July 08, 2016 to July 28, 2016. The article starts with the general situation of the Kashmir issue and then the encounter between the security forces and the militant Burhan Wani, young Hizbul Mujahideen commander from South Kashmir Tral area of Jammu and Kashmir. Before coming to the analysis of the various days protest and clashes, the article tells us the killing of Burhan Wani was announced by the Army on July 8, 2016 and after that the protests and clashes erupted in the paradise Kashmir and the 90 days long protest converted the Paradise into Lost Paradise. The article is well written by Meenakshi $R$ by giving the short overview of the daily protests after the killing of the Burhan Wani which is important in tracing and analysing the related content published in the regional newspapers, The Daily Excelsior and The Greater Kashmir.

ii. Framing Kashmir: How the Indian elite Press frames the Kashmir issue in its editorials by Shams Imran (2013), published in the International Journal of Communication and Social Research. In this Journal, Shams Imran highlighted the presentation of the Kashmir issues via different frames for the Kashmiri audience and for the Indian audiences by the Media houses. The author also developed the frames into eight different categories to understand how the press framed and continues to frame the debate on the Kashmir Issue;
a) History frame
b) Legality frame
c) Nation state frame
d) Law and order frame
e) Democracy frame

f) Human rights frame

g) International relations frame

h) Conflict resolution frame

i) Other frame which includes all those interpretations that are not covered in the said categories,

This analysis clarifies the contrast of framing the same issue in two newspapers of two different regions of the same state Jammu and Kashmir.

iii. Kashmir unrest prompts India's biggest crackdown in decades; an article in the Washington Post by Aijaz Hussain (2016): In this article the writer stressed upon the major crackdowns in the last two decades after the killing of the Burhan Wani in the valley. This crackdown by the security forces are carrying out their most severe crackdown in more than two decades against civilian protesters. The analysis of this article showed the situation of the Kashmir after the killing of a militant by the security forces and the post effects of the encounter resultant into the mass agitation by the local youths in support of the militants. The article also treated the conflict news with the frame of the old decades in which the protest in valley erupted for the Azaadi agenda which is also the part of the propaganda by the neighbouring state Pakistan.

iv. Jammu \& Kashmir suffered Rs16, 000 crore losses during unrest in 2016: This report was published by the Live Mint e-paper taken from PTI (2017), in which the report said that the Jammu and Kashmir suffered losses to the tune of over Rs16, 000 crores during the fivemonth long unrest in the Kashmir Valley due to complete halt of economic activity coupled with loss of property worth crores of rupees. The chapter "Economies of Uncertainty and Conflict" of the survey report tabled by minister for finance Haseeb Drabu in the Jammu and Kashmir Assembly said that in 2016, the civil strife caused tremendous miseries, loss of life, complete halt of economic activity in the Valley coupled with loss of property worth crores of rupees. It helped in understanding the aftereffects of the unrest.

\section{Objectives:}

In the backdrop of above mentioned scenario, this research would examine the following research questions:

i. The main objective of this work is to analyse the Kashmir unrest in the first week of the month of July and the comparison of the 
front-page coverage of this unrest by The Daily Excelsior and The Greater Kashmir newspapers.

ii. To investigate, whether there is an agenda in the coverage of newspapers of both the regions of Jammu and Kashmir related to the target audiences.

iii. To investigate, whether the coverage of Kashmir unrest in July 2016 showcases the framing of the same issues with the different narratives.

\section{Methodology:}

In Jammu and Kashmir, there are more than hundred English daily newspapers (RNI, 2017) having their own agenda based on their editorial policies and target audiences. Out of them the highest circulated newspaper of Jammu region, The Daily Excelsior and the highest circulated newspaper of Kashmir Valley, The Greater Kashmir are taken as samples. As this research is related to the Kashmir Unrest 2016 so the incident of the encounter of Burhan Wani was selected because after the killing of this militant, Kashmir witnessed more than three months long protests and unrest. How this unrest was covered by these two leading newspapers of the Jammu and Kashmir has been compared by comparing their headlines, photographs, space, content, placement and color used by the newspapers for the coverage of the same incident; however, this research is purely done to find out the narratives in both the newspapers and compare them. In Jammu, the leading newspaper Daily Excelsior has 2.3 lacs audiences (approx.) and in Kashmir, the leading newspaper Greater Kashmir has 1, 10,000 audiences (approx.). Both the newspapers having their own target audience with their own ideologies like in Jammu; Excelsior does not give any colour to the terrorism related activities and on the other hand, the newspaper like Greater Kashmir having the audience who wants the fullpage news item if there is any incident of terrorism related activity. For this reason, the front-page news related to the unrest in both the newspapers are analyzed for one week starting from from the first news of the killing of the Burhan Wani i.e. from 9thJuly 2016 to $15^{\text {th }}$ July 2016. Only one week's front-page news has been compared because the most intensified unrest was going on just after killing of Burhan Wani which was covered daily by both the newspapers and later the repetitive pattern of the news coverage by both the newspapers was found, so there was no point in carrying out analysis for more days. Also, the analysis of repetitive pattern of news coverage by both the newspapers in one week was enough to understand the framing of news to create narratives. It has been tried to find out the different narratives of these two newspapers of the two regions in the coverage of the same incident.

\section{Agenda Setting and Media Narratives:}

Agenda setting describes ability (of newspaper) to influence the salience of topics on the public agenda i.e.; if the news item is covered frequently and prominently the audience will regard the issue as more as important. This theory was developed by Dr. Max McCombs and Dr. Donald Shaw in a story on the American president elections in 1968. This theory can be traced to the first chapter of Walter Lippmann's 1922 book, Public Opinion.

In the media narratives discourse, the media agenda setting is being related with the analysis of the different frames of the single particular issue. In agenda setting, media first builds the agenda to cater their audiences. Agenda building refers to the process by which news organizations and journalists features, emphasize or select certain issues/events or sources to cover over others. It is also related to work in political science or policy agenda setting which focuses on how media/news coverage both reflects and shapes the priorities of government officials, decision makers and elites. And the same thing is the today's contemporary debate in front of the audiences that what they must read and from which newspaper? In this small research work, the agenda building by the newspaper establishments to cater their audiences and for the high circulation of their copies is being discussed. The only difference between the agenda setting and agenda building in the media narratives are;

Agenda setting: the media attempts to determine which stories to cover and how much time and effort to dedicate to those stories.

Agenda Building: how the media goes about gathering all the information which will be presented to the public in news stories.

For the newspaper of the Jammu and Kashmir, there are so many examples which relate the media agenda building and narratives; like the news about the hardcore separatists published in the Kashmir based newspapers and on the other hand, the same news not visible in the Jammu based newspaper and the only reason behind this is the agenda building of the Kashmir audience and Indian audiences respectively.

Also, in the recent incident of the human shield row in 2017, the Kashmir based newspapers covered the incident with the special interviews 
of the Human rights activists and on the other hand the Jammu based newspapers just reported the whole incident along with the Army version and the Major version. There are so many examples of the agenda building and setting by the media in Jammu and Kashmir in which some are discussed above.

\section{Analysis of the media narratives: How these two newspapers framed the issue}

In order to understand the Kashmir issue, one needs to realise and accept its complexity. depending on the side from where you view it, the conflict in Kashmir be a fight for identity or a fight against the state, as the remnants of partition or a fight against political status quo, the result of religious assertion or long denied political promises or just as a result of India-Pakistan friction. Moreover, Kashmir has often been described as the unfinished business of partition by the Pakistani leadership and the finished business of partition by the Indian leadership. The former tries to test the theory of two nations and the latter weighs it with the secular model. In between these two models are the helpless people of Kashmir who want to live their life with dignity.

The mass uprising in 2016; which was triggered by the death of Burhan Wani (the Hizbul commander) was continued for more than 100 days. The uprising had resulted in total shutdown throughout the Valley with massive protest marches. To prevent the marches and public meetings for "aazadi", the government came down heavily on the marchers resulting in clashes all over the Valley. Pellet guns, teargas, paper gas and even straight bullets were used to prevent assemblies and marches. Continuous curfew was imposed throughout the Valley. It was a virtual siege and the Valley was converted into a huge prison with the induction of additional troops.

To compare the tone and importance given by the two leading newspapers to the news published on the very next day of Burhan's encounter, let us compare the headlines, sub-headlines and lead given by the two leading newspapers of the two regions:

\begin{tabular}{|l|l|l|}
\hline & $\begin{array}{l}\text { Greater Kashmir } \\
\text { (July 9, 2017) }\end{array}$ & $\begin{array}{l}\text { Daily } \\
\text { Excelsior } \\
\text { (July 9, 2017) }\end{array}$ \\
\hline Headlines & $\begin{array}{l}\text { Burhan Killed, } \\
\text { Kashmir on Boil } \\
\text { (Banner Headline) }\end{array}$ & $\begin{array}{l}\text { Top Hizb } \\
\text { comdr Burhan } \\
\text { Wani among 3 } \\
\text { killed } \\
\end{array}$ \\
& (Double deck, \\
& & three column \\
\hline
\end{tabular}

\begin{tabular}{|c|c|c|}
\hline & & headline) \\
\hline $\begin{array}{c}\text { Sub- } \\
\text { Headlines }\end{array}$ & 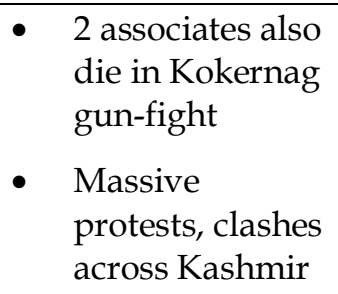 & $\begin{array}{l}\text { Curfew like } \\
\text { restrictions in } \\
\text { Srinagar, } \\
\text { Pulwama, } \\
\text { Anantng. }\end{array}$ \\
\hline Lead & $\begin{array}{l}\text { Top Hizb-ul- } \\
\text { Mujahideen } \\
\text { commander Burhan } \\
\text { Muzaffar, the face of } \\
\text { new age militancy } \\
\text { in Kashmir who } \\
\text { carried a bounty of } \\
\text { Rs 10,00000, died in } \\
\text { a gun fight with } \\
\text { forces in Kokernag } \\
\text { area of South } \\
\text { Kashmir's } \\
\text { Anantnag district } \\
\text { on Friday, } \\
\text { triggering massive } \\
\text { anti-India and pro- } \\
\text { freedom protests } \\
\text { across Kashmir and } \\
\text { a state-wide } \\
\text { shutdown call by } \\
\text { separatist } \\
\text { leadership. }\end{array}$ & $\begin{array}{l}\text { Top } \\
\text { commander } \\
\text { of Hizbul } \\
\text { Mujahideen, } \\
\text { Burhan Wani, } \\
\text { was killed this } \\
\text { evening along } \\
\text { with his two } \\
\text { associates in } \\
\text { South } \\
\text { Kashmir. }\end{array}$ \\
\hline
\end{tabular}

It is obvious from the above table that the Daily Excelsior has reported the news in most neutral and simplistic manner by giving only three column story with a picture; the Greater Kashmir has flared it up by adding heroic introduction of the militant in lead like 'the face of new age militancy', 'carried a bounty of Rs. 10, 00000' and highlighting the widespread impact of his death. Also, the headline of Greater Kashmir does not identify Burhan Wani as Hizb commander and mentions only his name in very big font size as if the audience knows him very well. The pictures of the stories covered by these two newspapers on their front page are as follows:

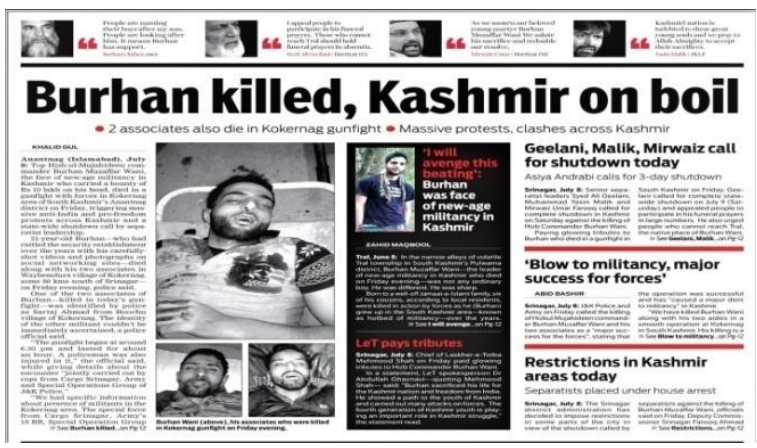

Picture 1- 9th July, 2016 (GK) 


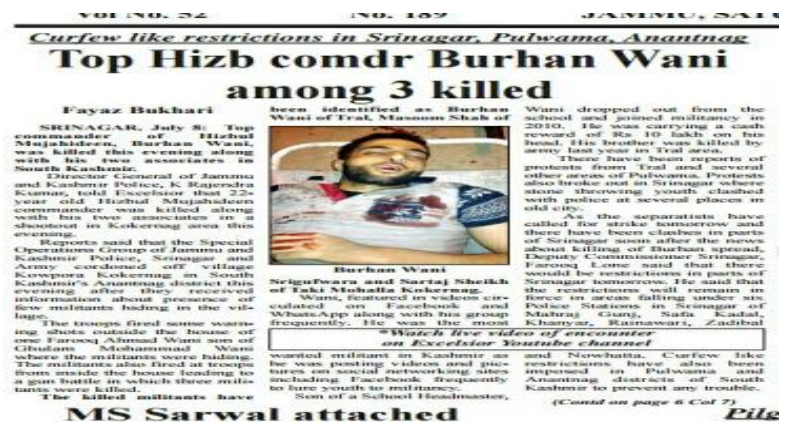

Picture 2 - 9th July 2016 (DE)

Whenever framing of the issues by the various media and newspaper groups discussed in any platform, we need to consider some of the ways in which media texts mediate the world to us. It has been already stated that, one of the most important ways of framed mediated communication is through the codes and conventions of narratives. Here we can use the Hall's Encoding/Decoding \& Ideology of News given as given in Laughey (2007) as follows:

Media institutions and the text they generate are important ideological dimensions through which we make sense of the world. Hall deploys semiotics to understand the sense making process by which media transmit messages to their audiences. Language is encoded (made to mean something) by those with the 'means of meaning production' (i.e. producers) and is then decoded (made to mean something) by audiences.

He also gave a model of media production and reception which is commonly known as the Encoding/Decoding model as shown below:

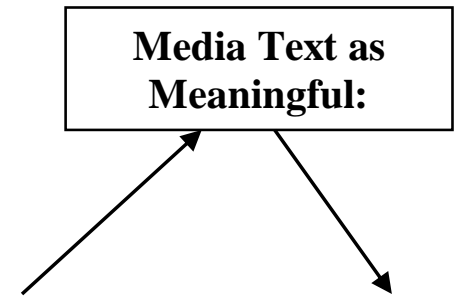

\section{Encoding}

Meaning structures1

\section{Decoding}

Meaning structures 2

2. Reception of Text

1. Production of Text

2. (A) Dominant Code

2. (B) Negotiated Code

2. (C) Oppositional Code

The above structure was given by the Stuart Hall in 1973 and taken from Laughey (2007). Hall's argument is that encoding of media content is done within a set of professional codes which generate preferred meanings that 'have the institutional/political/ideological order imprinted in them' and can be decoded in any of the three decoding codes given in the model shown above.

For instance, the news of Burhan Wani killing was carried by the both the leading newspapers of Jammu and Kashmir but with different angles in lead, headlines and sub headlines keeping in mind the line of thoughts of their audiences of Jammu region and Kashmir region respectively. The Kashmir centric newspaper Greater Kashmir used the word 'forces' in lead which is understood as Indian forces or government forces by Kashmiri audiences and played up the news by adding heroic description of the militant while on the other hand the Jammu centric newspaper Daily Excelsior did not use such words at all and framed the news in most neutral and simplistic way. The framing of the same issue using the word forces is an encoded message by the media services which influences the audience of the region. They decoded the same message as sympathy from the newspaper for the militant and anger for the security forces. This is an example of Hall's Dominant Code (1973), according to which, the audience takes the actual meaning directly and decodes it exactly the way it was encoded. The consumer is located within the dominant point of view and is fully sharing the texts codes and accepts and reproduces the intended meaning.

Let us compare the other related news items published in both the newspapers on July 9, 2016 after the killing of Burhan Wani:

\begin{tabular}{|l|l|l|}
\hline & $\begin{array}{l}\text { Greater Kashmir } \\
\text { (July 9, 2016) } \\
\text { Picture and 5 5 } \\
\text { shown below }\end{array}$ & $\begin{array}{l}\text { Daily } \\
\text { Excelsior } \\
\text { (July 9, 2016) } \\
\text { Picture 3 } \\
\text { shown below }\end{array}$ \\
\hline $\begin{array}{l}\text { Headline } \\
\mathbf{1}\end{array}$ & $\begin{array}{l}\text { 'I will avenge this } \\
\text { beating': Burhan was } \\
\text { face of new-age } \\
\text { militancy in Kashmir }\end{array}$ & $\begin{array}{l}\text { Yatra } \\
\text { suspended for } \\
\text { today, direct } \\
\text { vehicles } \\
\text { stopped on } \\
\text { NH due to } \\
\text { Valley unrest }\end{array}$ \\
\hline $\begin{array}{l}\text { Sub- } \\
\text { Headline }\end{array}$ & $\begin{array}{l}\text { No sub-headline } \\
\text { crosses one } \\
\text { lakhs in just 7 } \\
\text { days. }\end{array}$ \\
\hline Content & $\begin{array}{l}\text { Born to a well-off } \\
\text { Jamaat-e-Islami } \\
\text { family, six of his } \\
\text { cousins, according to } \\
\text { local residents, were } \\
\text { killed in action by } \\
\text { forces as he (Burhan) }\end{array}$ & \\
\hline
\end{tabular}




\begin{tabular}{|c|c|c|}
\hline & $\begin{array}{l}\text { grew up in the South } \\
\text { Kashmir area- } \\
\text { known as hotbed of } \\
\text { militancy-over the } \\
\text { years. }\end{array}$ & \\
\hline $\begin{array}{l}\text { Headline } \\
2\end{array}$ & $\begin{array}{l}\text { Masjids } \\
\text { with reverberates } \\
\text { slogans }\end{array}$ & $\begin{array}{l}\text { No other } \\
\text { story }\end{array}$ \\
\hline $\begin{array}{l}\text { Sub- } \\
\text { Headline }\end{array}$ & $\begin{array}{l}\text { Protests in Srinagar, } \\
\text { Baramulla, } \\
\text { Anantnag, Pulwama, } \\
\text { elsewhere }\end{array}$ & $\begin{array}{l}\text { No sub- } \\
\text { headline }\end{array}$ \\
\hline
\end{tabular}

This is a perfect example of Oppositional Code / Position in which a consumer understands the literal meaning but due to different backgrounds everyone has their own way of decoding messages, while forming their own interpretations and there is a direct oppositional relation to the dominant code and they do not share the text code and end up rejecting it (Hall, 1973).

Daily Excelsior carried two news items on 9th July 2016; one was the killing of Burhan Wani with a simple headline and other was the disturbance in the yearly Amarnath yatra 2016 due to the unrest which clearly indicates the simplistic approach of the newspaper keeping in mind the sentiments of the people of Jammu region who are more concerned about Amarnath Yatra and killing of Burhan Wani is just like killing of any other militant for them. The picture of the story published is as follows:

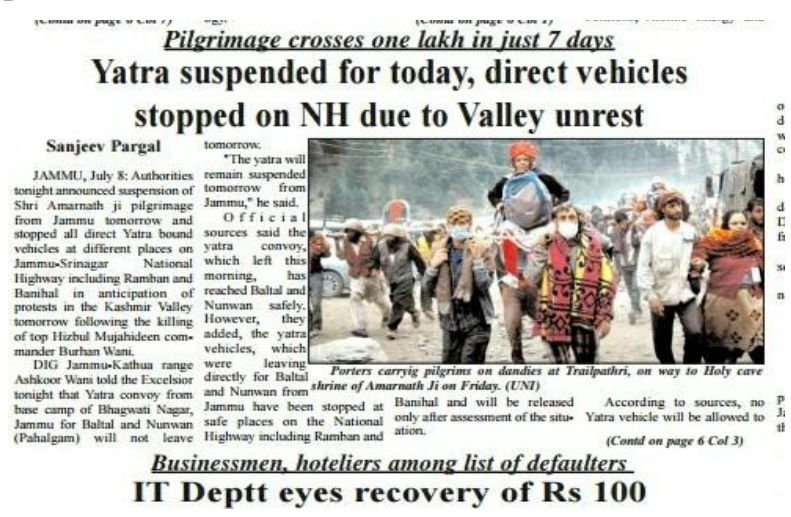

Picture 3 - 9th July 2016 (DE)

Whereas, following the sentiments of Kashmiri audiences, Greater Kashmir published an emotionally wrapped heroic profile of Burhan Wani on the same day which is very much obvious from the tone and content of the headlines given above. It has published one more related news story echoing the popularity of Burhan Wani with headline. 'Masjids reverberate with pro-Burhan slogans'. The picture of the story published is as follows:

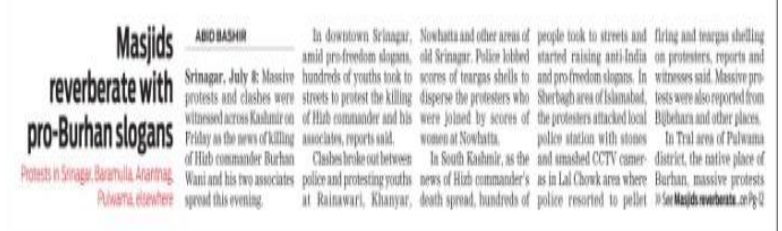

Picture 4 - 9th July, 2016 (GK)

Even there were oppositional positions in the pictures used by these two newspapers too. There were pictures of bodies of all three militants killed in the encounter published in the Greater Kashmir along with a heroic picture and profile of Burhan Wani. The picture published in Greater Kashmir is shown below:

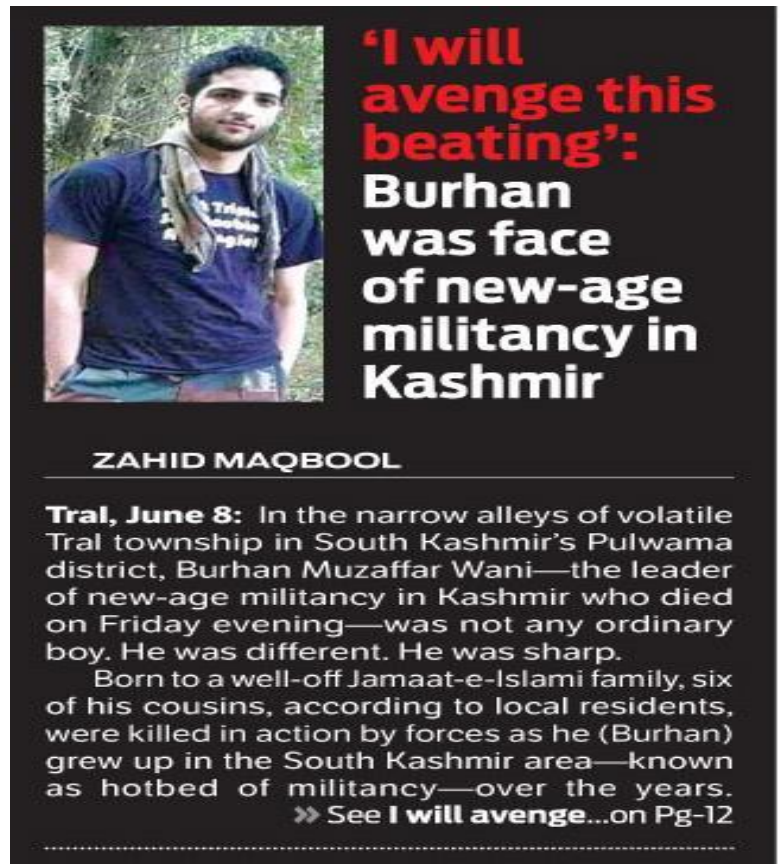

Picture 5 - 9th July, 2016 (GK)

On the next day of the Burhan Wani killing, on $9^{\text {th }}$ July, 2017, Greater Kashmir copy came with the front page news item with more than half page space with the photographs of other militants along with the Burhan Wani photograph and also used some quotes like, "Burhan Wani was face of new age militancy in Kashmir". Also, there was a block item which was filled by black color in which Lashkar militant was paying the homage to the Burhan Wani.

On the comparison of the both newspapers, the photo content also high jacked the minds of the audiences; the Greater Kashmir has used the photograph of the Burhan Wani in a Heroic pose so that he will be in the minds of the youngsters as a hero who was fighting for the freedom of the Kashmir. And the newspaper, Daily Excelsior used only one picture of the body of the Burhan Wani on front page along with news item in a small column so that there will be a message to 
the audience that this is the only end of the militancy.

From the above example the same news was framed for the different audiences; on one hand, the news is presented like the general information that some militant was killed in an encounter with security forces and on the other hand, the same news is framed to gain the sympathy among the audiences of the Kashmir by the two newspapers.

Analysis of the content, placement of stories and colours used as codes in the highly circulated newspapers of Jammu region and Kashmir region:

The 2016 Unrest in Kashmir was also known as the post Burhan Wani killing unrest as the Hizbul Mujahideen, militant commander, Burhan Wani was killed in the month of July 2016 in an encounter with the security forces which lead to the series of the violent protest in the valley.

Also, this 2016 unrest was the biggest unrest till reported in the Kashmir valley and the backing of this unrest was the youngsters as Burhan Wani cultivated the azaadi agenda within the brains of the Kashmiri youths with his video clips on the social sites.

The art of analyzing the newspapers are through the pictures they used and all the content they used in their newspapers whether in the form of the colored headlines or the sub headlines. The newspaper like Greater Kashmir and Daily Excelsior with their different tastes of audiences, produced the content as per the likings of their respective audiences, which are tried to highlight in this research and tried to show the difference of the ideologies of the newspapers which gives birth to the narratives within the media and also the regional war inside media coverage.

Now, some of the newspaper cuttings of both the highly circulated newspapers Greater Kashmir and Daily excelsior are shown below along with the description of their content, placement, space, color etc. which shows the different ideologies of the newspaper houses and also their audiences. And that's the only reason for which the Kashmir audiences only like to read Greater Kashmir and the public of Jammu like to read the Daily Excelsior or other Jammu based newspapers. Also, there are some incidents reported in Jammu as well as in Kashmir in which the copies of these newspapers were also used in the protests. Jammu protestors criticized the Kashmir newspapers for their publications in favor of the militants and other separatist leaders.
Comparison of the front pages of Greater Kashmir and Daily Excelsior of 10 ${ }^{\text {th }}$ July, 2016

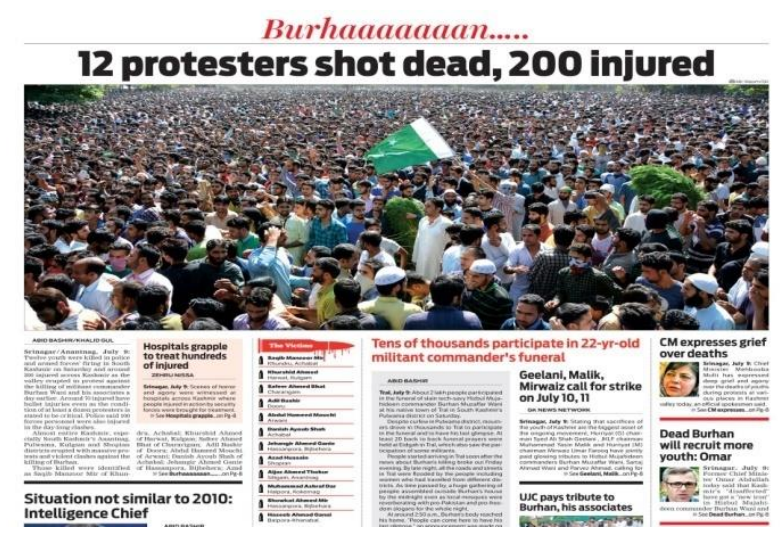

Picture 6: 10th July, 2016 (GK)

Another copy of the Greater Kashmir newspaper with the front page news item of the Burhan Wani killing post clashes incident with the major headline in red color "Burhaaaaaaaan" which showed the sympathy for the militant and an agenda against the Indian Government. The photograph that used by the news item had covered the half page space in which youth in thousands of numbers unfurling the other country flag in their own motherland. All this color ideology cultivates the hatred against the Indian security forces and sympathy among the militants who took the guns against India.

Whereas, the headline of Daily Excelsior 'Widespread violence leaves 12 dead, 160 including 96 security men injured' is more sympathetic towards security forces and frames them as victims not perpetrators. Daily Excelsior carried the front-page news of the clashes erupted in the Kashmir with a photograph of the security personnel firing a tear gas shell on the protester. It had a sub headline of the mobile internet restrictions and other curfew situation in the valley. The front-page news also carried the information for the Amarnath yatra suspension which was mostly missing in the Kashmir based newspapers. The yearly Amarnath yatra also suffered a lot in this phase of the unrest after the killing of Burhan Wani in 2016. Picture of front page is as shown below:
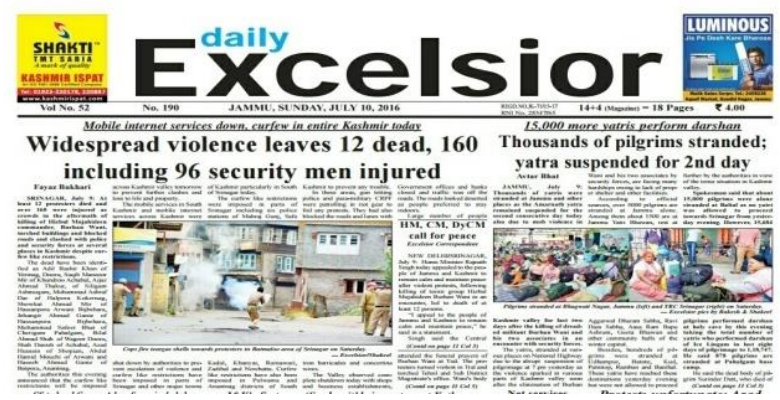

Picture 7: 10th July, 2016 (DE) 
Comparison of the front pages of Greater Kashmir and Daily Excelsior of $11^{\text {th }}$ July, 2016

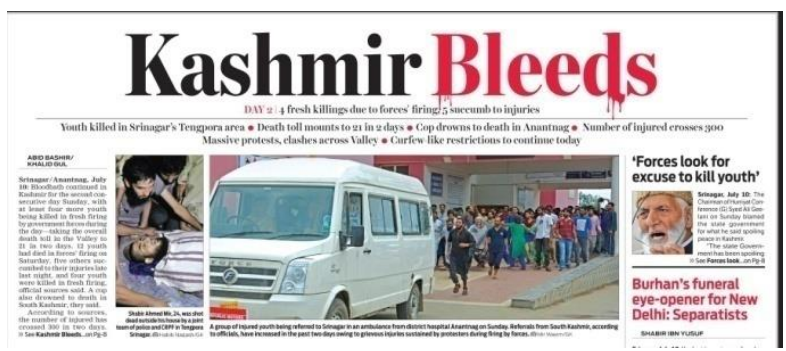

Picture 8 - 11th July, 2016 (GK)

This is the copy of Greater Kashmir newspaper published on 11 July 2016 in which the Kashmir newspaper used the red color in the headline Kashmir Bleeds which directly shows the ideology of the newspaper in which the newspaper seeking the sympathy for the militant Burhan Wani who killed by the security forces in an encounter. The news carried on the front page along with the statement of the separatist leader Syed Ali Shah Geelani. This headline Kashmir Bleeds also having the graphic of the blood drops coming out from the Bleeds word which also seeks the attention of the readers and cultivated the sympathy for the militants who took guns against the security forces.

Whereas, the Daily Excelsior again reported the news of death toll including security personnels and about the Amarnath Yatra as two most prominent stories. Also, picture used in the stories were giving an impression of downplaying the unrest of Kashmir. The picture of front page is shown below:

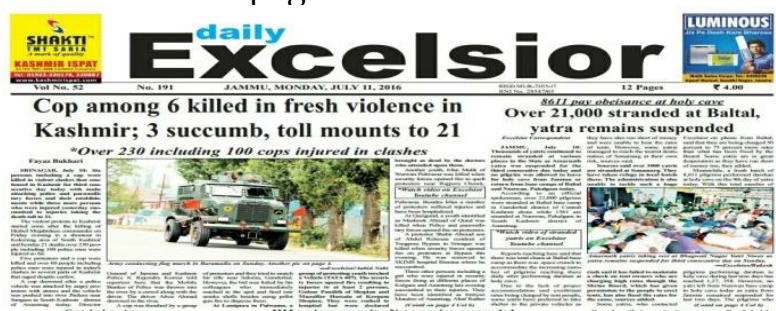

Picture 9: 11th July, 2016 (DE)

Comparison of the front pages of Greater Kashmir and Daily Excelsior of 12 th July, 2016

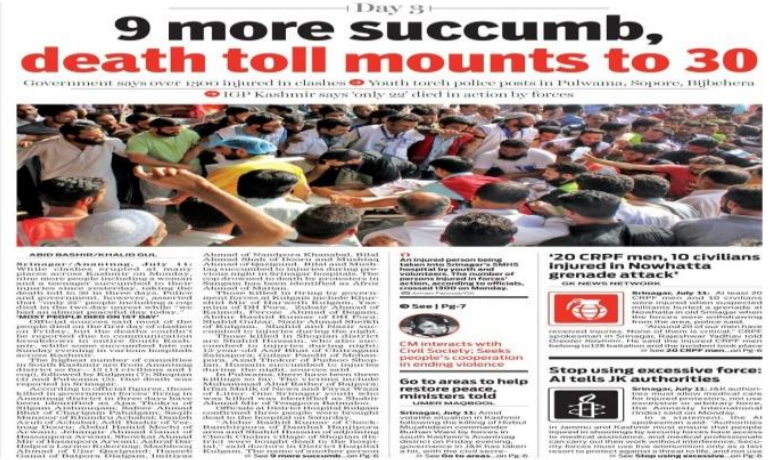

Picture 10: 12th July, 2016 (GK)
The day $3^{\text {rd }}$ day copy of the Greater Kashmir again produced with the color ideology in which the headline carried black and red color " 9 more succumb, death toll mounts to $30^{\prime \prime}$ the "death toll mounts to $30^{\prime \prime}$, highlighted with red color which is in tune with the sentiments of the audiences and cultivates hatred against the state and on the other hand supports the hidden agenda of the Kashmiri separatists. And the youth photograph also used along with the headline that killed in the ongoing clashes with the security forces. Also, one of the major highlight was the wanted terrorist Salahuddin's statement of sympathy for the Kashmiri youths carried by the Greater Kashmir. However, there were some small block items of the Prime Minister Narendra Modi and Home minister Rajnath Singh appeal for the restoration of peace.

Whereas, after two days of the Burhan Wani killing, Daily excelsior carried the general news of the clashes between the youth and the Indian Army in which the death toll reached 30 . No color or special characters and graphics used for the headlines of this news, and the basic agenda of this newspaper seems to be only to inform the public about the situation of the valley as that month was also an important month for the Kashmir tourism and the tourism industry also suffered a lot during unrest of the Kashmir valley.

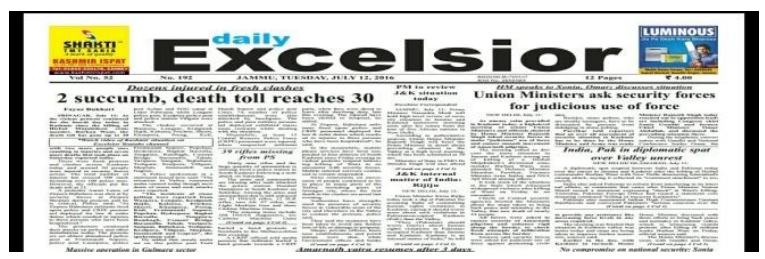

Picture 11: 12th July, 2016 (DE)

Comparison of the front pages of Greater Kashmir and Daily Excelsior of $13^{\text {th }}$ July, 2016

\section{Teenager killed in Kupwara,} death toll 32 in 4 days

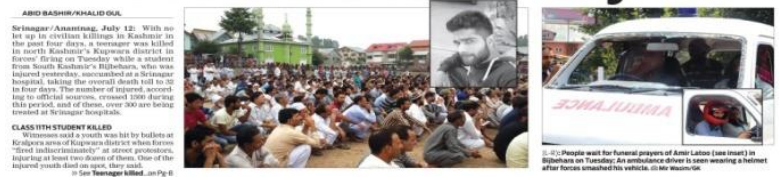

Picture 12: 13th July 2016 (GK)

On the $4^{\text {th }}$ day after the killing of Burhan Wani, the Greater Kashmir copy once again came with blood graphics as seen in the above picture along with the headline "teenager killed in Kupwara death toll 32 in 4 days "this headline also having the red color on the death toll and other highlighters on the left side of the copy with the names of all the deaths in the 4 days of the unrest. Also, the copy contained the PM Modi review 
meeting and statements of former $\mathrm{CM}$, Omar Abdullah, Home Minister, and Rajnath Singh.

The colour ideology used in headlines and sympathy towards protesters is clearly visible in the reporting of newspaper Greater Kashmir. The feeling of hidden hatred towards state can be easily sensed which may satisfy the latent anger of the target audiences of Kashmir valley.

Now, here is the cutting from the newspaper Daily Excelsior published on 13th July, 2016 in which the newspaper used the statement of the Chief minister, Jammu and Kashmir, Mehbooba Mufti in which she appealed the youth for the peace process and the other news carried by the paper in which a high level meeting chaired by the Prime Minister Narendra Modi on Kashmir unrest and asked J\&K government to take necessary steps for the peace in state. And small column news of clashes erupted in the valley after the killing of the Burhan Wani.

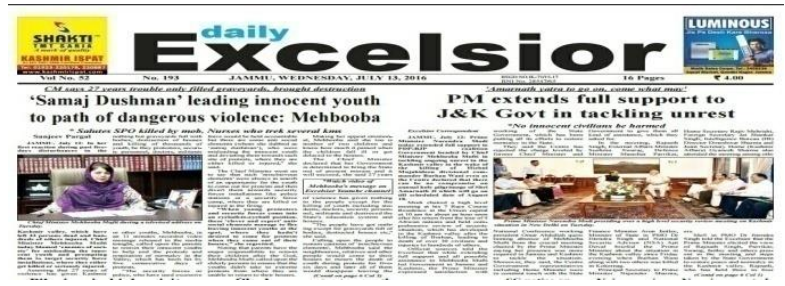

Picture 13: 13th July, 2016 (DE)

Comparison of the front pages of Greater Kashmir and Daily Excelsior of 14 ${ }^{\text {th }}$ July, 2016

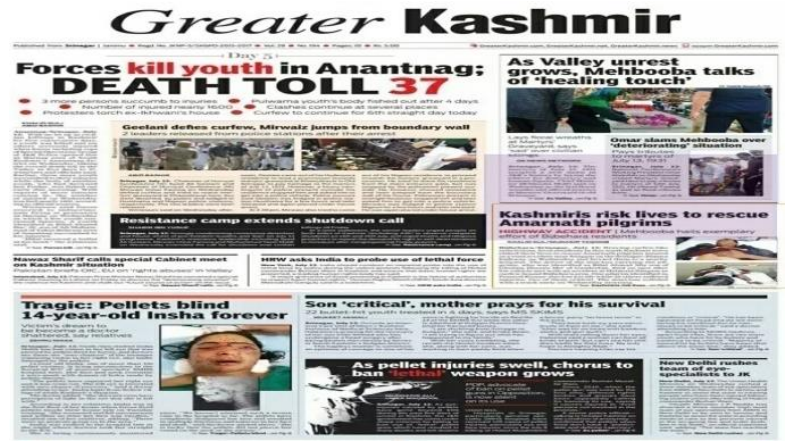

Picture 14: 14th July, 2016 (GK)

On the $5^{\text {th }}$ day of the unrest, the front page of Greater Kashmir carried almost all news items related to this unrest. While one side it published the lead story with headline 'Forces killed youth in Anantnag; DEATH TOLL 37' by again using the colour combination of red and black, the next story it published was about the statement of 'healing touch' by Chief Minister Mehbooba Mufti amidst growing unrest in Kashmir. The other news items on front page were related to the tragic outcomes of government actions against the protesters including one news of a Kashmiri who saved one of the Amarnath pilgrim; which in a way to show the humanitarian face of Kashmiris and inhuman suppression by the government.

\begin{tabular}{|c|c|c|}
\hline & $\begin{array}{l}\text { Greater Kashmir } \\
\text { (July 14, 2016) } \\
\text { Picture 14 shown } \\
\text { above }\end{array}$ & $\begin{array}{l}\text { Daily Excelsior (July } \\
\text { 14, 2016) } \\
\begin{array}{l}\text { Picture } 15 \\
\text { below }\end{array}\end{array}$ \\
\hline $\begin{array}{l}\text { Headline } \\
1\end{array}$ & $\begin{array}{l}\text { Forces killed youth } \\
\text { in Anantnag; } \\
\text { DEATH TOLL } 37\end{array}$ & $\begin{array}{l}3 \text { more die, toll } \\
\text { reaches 36, } 1500 \\
\text { injured in clashes }\end{array}$ \\
\hline $\begin{array}{l}\text { Sub- } \\
\text { Headline }\end{array}$ & Not significant & No sub-headline \\
\hline $\begin{array}{l}\text { Headline } \\
2\end{array}$ & $\begin{array}{l}\text { As valley unrest } \\
\text { grows, Mehbooba } \\
\text { talks of 'healing } \\
\text { touch' }\end{array}$ & $\begin{array}{l}\mathrm{CM} \text { seeks people's } \\
\text { support to bring J \& } \\
\mathrm{K} \text { out of violence, } \\
\text { bloodshed }\end{array}$ \\
\hline $\begin{array}{l}\text { Sub- } \\
\text { Headline }\end{array}$ & No sub-headline & $\begin{array}{l}\text { 'Won't let people } \\
\text { down, despite tough } \\
\text { task' }\end{array}$ \\
\hline
\end{tabular}

While on the other side, Daily Excelsior carried three stories related to the unrest, out of which the lead story tells ' 3 more die, toll reaches 36 , 1500 injured in clashes' with a picture in which protestors have blocked the road.

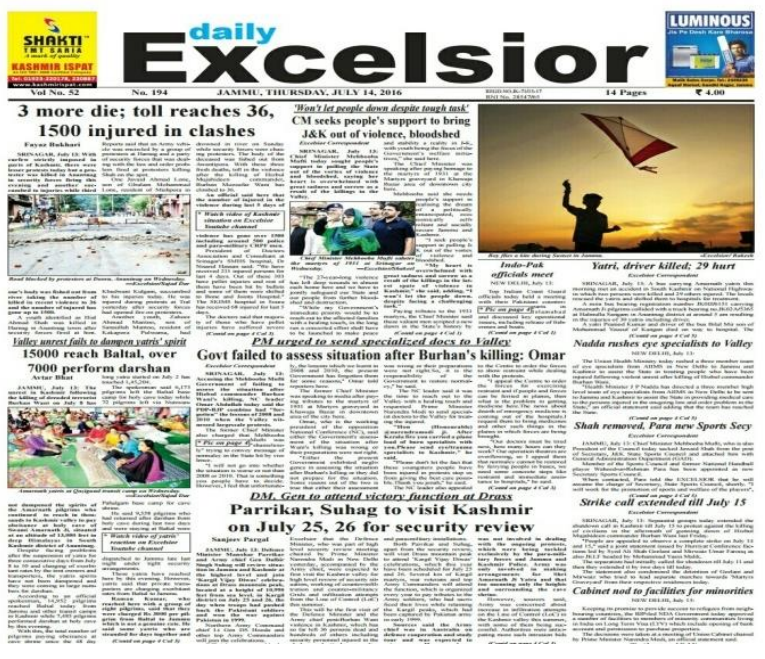

Picture 15: 14th July 2016 (DE)

In the lead headline, Greater Kashmir bluntly says 'Forces Killed' while the Daily Excelsior says 'injured in clashes' which means Greater Kashmir tries to portray security forces as perpetrators and held them responsible for violence and unrest in valley while Excelsior tries to portray both sides responsible that's why it used the word 'clashes'. In the Greater Kashmir's second headline, as valley unrest grows, Mehbooba talks of 'healing touch': one can easily sense the sarcastic connotation where 'healing touch' has been kept under inverted comma and compared with growing unrest in valley. While the second headline of Daily Excelsior simply gives impression that the people of $\mathrm{J} \& \mathrm{~K}$ are indulged in violence and bloodshed. 
Comparison of the front pages of Greater Kashmir and Daily Excelsior of $15^{\text {th }}$ July, 2016

\section{Greater Kashmir}

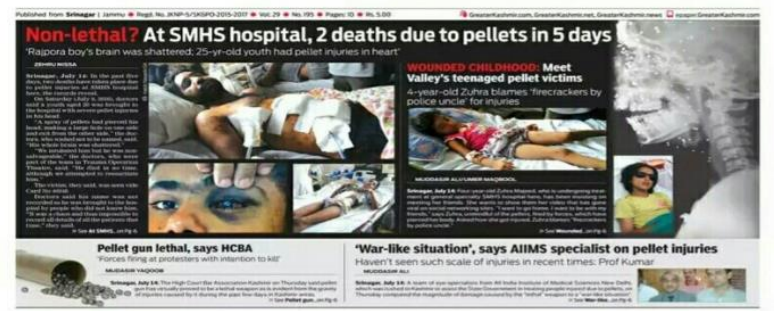

Day 6: Kulgam teenager India, Pak spar over Kashmir dies, toll mounts to 38

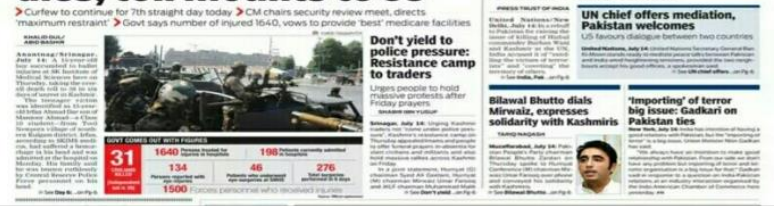

Picture 16: 15th July, 2016 (GK)

Another copy of the Greater Kashmir published on the $6^{\text {th }}$ day after the killing of the Burhan Wani and front page has been given for the whole incidents of the 6 days in which the hospital specialist quotes has been used "war like situation" this quote by the AIIMS specialists for the unrest in Kashmir. The above pictures used on the front page with mostly red and black colour combination in order to intensify the severity of situation.

Whereas, the Daily Excelsior talks about imposition of curfew across Kashmir in its lead headline and highlights the number of injured security forces in the sub-headline and the second lead news is also about shifting of security forces to valley which clearly indicates its inclination towards the security forces and government.

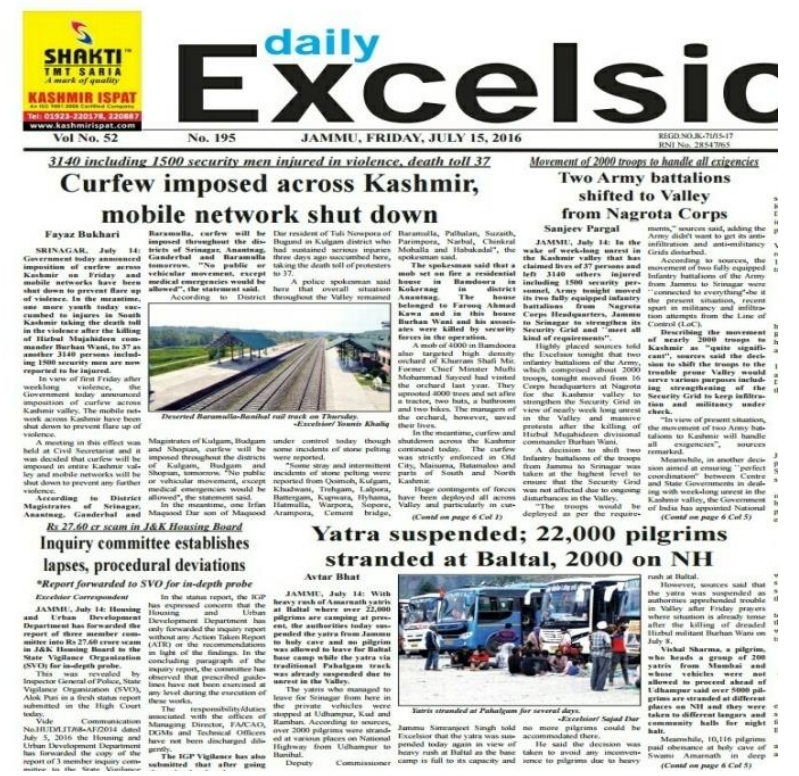

Picture 17: 15th July 2016 (DE)
Comparison of the front pages of Greater Kashmir and Daily Excelsior of $16^{\text {th }} \mathrm{July}, 2016$

\section{Greater Kashmir}

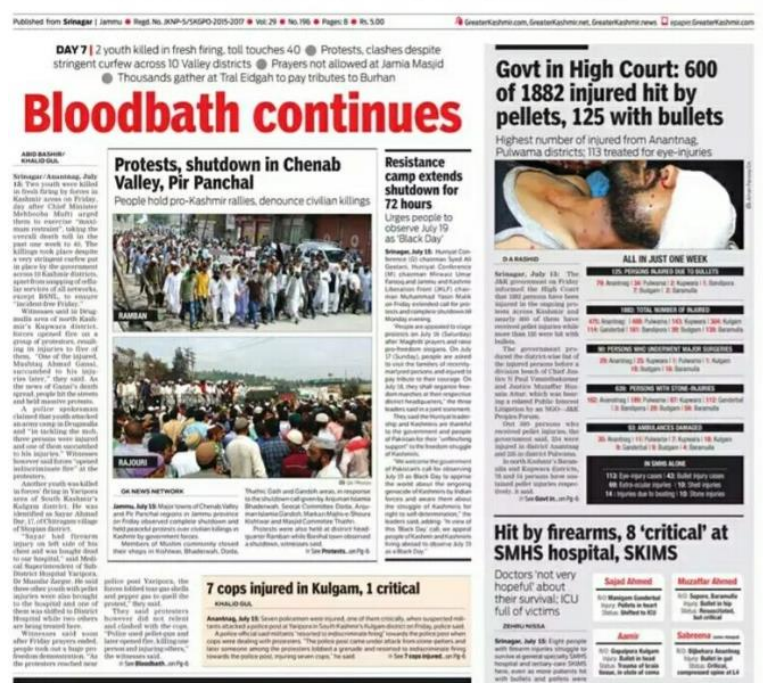

Picture 18: 16th July, 2016 (GK)

Another copy of Greater Kashmir also came with the red colored headline "Bloodbath continues" with the two photographs from the other districts of the state in which the protests and clashes erupted and the on the right side of the newspaper front page the photograph showing the youth injured in a pellet gun fire which also resultant into the more clashes in the coming days and led the whole unrest to the year-long unrest in the valley which is one of the longest unrest recorded in the Jammu and Kashmir.

Whereas, same day the Excelsior copy published the headline ' 2 killed, 23 injured as mobs defy restrictions' with a picture of road filled with stones pelted by the protesters. This headline clearly held the mob's actions responsible for the killing and injuries and it is further supported by the picture of stones filled road. Mob itself is a negative word which generally means a violent crowd. There are other two news items about the Amarnath Yatra and how it is disrupted by the unrest.

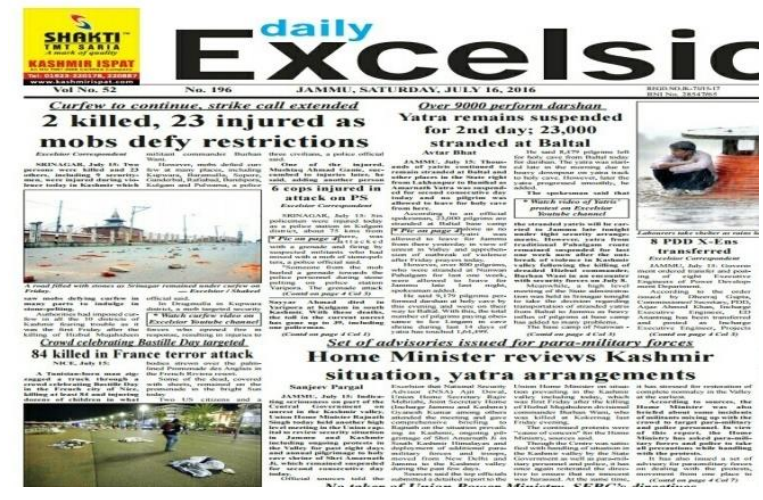

Picture 19: 16th July 2016 (DE) 
Greater Kashmir is also having the YouTube channel and mobile applications in which they have more than 19000 subscribers and on this channel, they uploaded a special documentary on the killing of the Burhan Wani and other clashes erupted during his killing in the valley. And this 2 minutes video got more than $84 \mathrm{k}$ views with a special footnote.

"Sea of people at Burhan Wani's funeral in South Kashmir"

\section{Conclusion}

There is no doubt that the state of Jammu and Kashmir is one of the most disturbed states of India and exactly therefore the role of media becomes very crucial here. But this is unfortunate that the media does not restrain itself to act as a player in the crisis forgetting its very precise role of informing people without further flaring the situation.

There are clearly two types of narratives visible within the state according to the above analysis, where the Jammu centric highly circulated newspaper Daily Excelsior narrates pro-state stories and Kashmir centric highly circulated newspaper Greater Kashmir narrates proseparatist stories against the state which are also influenced by the not so friendly neighboring countries Pakistan and China.

Media of Jammu region and Kashmir region is totally different in working; we can judge the differences with the comparison of front page news items of both the regions newspaper during the unrest. As, one is full of Kashmir unrest pictures and news contents and other one having the small news item of the same unrest and rest are other stories. So, the youth ideology is developed with the contents of their respective area newspaper and the youth mind become constructive or destructive respectively.

This research is carried under the theoretical frameworks of Agenda Setting Theory which is the most commonly used media theory in these types of the conflict situations and under this frameworks the analysis of front page news of these two prominent newspapers of Jammu and Kashmir have been clearly seen to propagate certain agenda which are reflected from the headlines, sub-headlines, lead, pictures, placement and the contents of the newspapers stories whether it is Kashmir based or Jammu based. The framing of the newspaper content set as per the taste of their audience in which Jammu based paper used nationalistic approach to cater their national centric audiences and Kashmir based newspapers used pro-Kashmiri approach to cater their Kashmir centric audiences. The issues are framed differently to build and support an agenda in favour or in opposition of the state in the two very significant regions of the same state.

The conclusion of this research is that this is not the new issue for the state like Jammu and Kashmir as the media playing very important role in restoring normalcy in the state. But somehow, media wants its own vested interest for the circulation of the more copies among the youth and other target audience without thinking of the state. And the narratives came into existence within a state based on the region and ideology, this research is only based on the comparison of the newspapers which is the part of the print media. But, in this present scenario the state is suffering a lot from the advent of the online media as this case of Kashmir unrest can also be said the result of the online media/ new media because Burhan Wani was one of the heroic face for the youth of Kashmir who used new media as a tool for injecting the hidden agenda of the militancy and other propaganda of the neighboring state Pakistan and China. References:

Ahmad, S. (2016). Kashmir Unrest 2016: A Story of Agony and Animosity. Mainstream, Vol. LIV (46). Retrieved fromhttp:/ / www.mainstreamweekly.net/ article6802.html

Car, V. (n.d.). Myths in Media Text. Retrieved from https://hrcak.srce.hr/file/61756.

Fulton, H. (2005). The Power of Narrative, in H. Fulton, R. Huisman, J. Murphet and A. Dunn (eds) Narrative and Media. Newyork: Cambridge University Press, 1-7.

Hall, S. (1985) The rediscovery of ideology: return of the repressed in media studies, in M. Gurevitch, T. Bennett, J. Curran and J. Woolacott (eds) Culture, Society and media. London: Routledge, 56-90.

Hussain, A. (2016, October 10). Kashmir unrest prompts India's biggest crackdown in decades. TheWashington Times. Retrieved fromhttp://www.washingtontimes.com/n ews/2016/oct/10/indian-troops-battlesuspected-rebels-in-kashmir

Imran, S. (2013). Framing Kashmir: How the Indian elite Press frames the Kashmir issue in its editorials. International Journal of Communication and Social Research. Vol. 1 (1). Srinagar: Central University of Kashmir, Jammu \& Kashmir suffered Rs16, 000 crore 
losses during unrest in 2016. (2016, January 10). Retrieved from http://www.livemint.com/Politics/tplII4 W1WjFelD52d9H4OO/Jammu--Kashmirsuffered-Rs16000-crore-loss-during-unresti.html

Laughey, D. (2007). Key themes in Media Theory. London: Open University Press.
Lippmann, W. (1922). Public Opinion. Newyork: Macmillan,

Meenakshi R. (2016, July 21). Kashmir on the boil: a timeline. The Hindu. Retrieved fromhttp://www.thehindu.com/news/nat ional/kashmir-unrest-after-burhan-wanisdeath/article14596369.ece. 